\title{
Effects of grass suppression on legume abundance during two contrasting seasons on a summer-dry hill country site
}

\author{
C. HEPP ${ }^{1}$, I. VALENTINE 2 , J. HODGSON ${ }^{2}$, A.G. GILLINGHAM ${ }^{3}$ and P.D. KEMP ${ }^{2}$ \\ ${ }^{1}$ Instituto de Investigaciones Agropecuarias (INIA), Chile \\ ${ }^{2}$ INR, Massey University, Palmerston North \\ ${ }^{3}$ AgResearch Grasslands, Palmerston North \\ chepp@tamelaike.inia.cl
}

\begin{abstract}
The low level of legumes in New Zealand hill pastoral systems is a recognized problem that is likely to affect sustainability. The relative importance of the factors that cause low legume abundance has not been sufficiently tested, especially on dry hill country. This paper reports the effects of grass suppression in two contrasting years in a summer-dry hill country site on the east coast of the North Island. Suppressing grass with haloxyfop herbicide (Gallant) in late autumn increased legume abundance by $>25 \%$ in both years, but the response patterns were strongly influenced by soil moisture status. Moist late spring and summer conditions produced $34 \%$ more legume growth in both \pm herbicide treatments. Residual effects of grass suppression favoured white clover over subterranean clover growth under moist seasonal conditions. The control of grass growth in these hill swards improved legume abundance, but the overriding factor affecting legume content in the pasture was the level of soil moisture.
\end{abstract}

Key words: grass suppression, haloxyfop herbicide, hill country, legume abundance, soil moisture, subterranean clover, summer-dry, white clover

\section{Introduction}

Low abundance and poor persistence of legumes is a generalised problem in hill country pastures, even at adequate soil phosphorus levels (Woodfield \& Caradus 1996). Likely causes for low legume contents in swards include lack of soil moisture, high temperatures (Barker et al. 1993), increased grass competition due to increasing fixed nitrogen content in the soil (Lambert et al. 1982), and frequency and intensity of defoliation (Suckling 1975; (Lambert et al. 1982). While considerable effort has been made to reintroduce legumes through over-sowing of dry hill country pastures, success has generally been limited (Awan \& Kemp 1994). On dry hill country, legume content of the swards is generally low and unpredictable due to inter-annual rainfall variability.
Resident pastures have been found to contain between 2 and 5\% white clover content between years (Barker \& Dymock 1993; Orr \& Wedderburn 1996). Gillingham et al. ( 1998) observed subterranean clover levels of only $2-4 \%$, even at Olsen P of 28 and especially where $\mathrm{N}$ fertiliser had been applied. The relative importance of some factors that cause low legume abundance has not been sufficiently tested, especially on dry hill country. Herbicide use has been tested as a means of reducing competition for legume seedling establishment and to produce botanical changes favouring legumes (Rolston et al. 1985; Sheldrick et al. 1993), but variability in soil moisture regimes may interact with and differently affect legume species abundance. A set of trials was established to evaluate the relative importance of factors limiting legume abundance in contrasting hill country pastures. This paper reports only on the short-term and residual main effects of grass suppression on legume abundance on a summer-dry hill country site, at Waipawa (Hawke's Bay).

\section{Materials and Methods}

\section{Site}

The experiment was located approximately $4 \mathrm{~km}$ west of Waipawa in the summer-dry hill country area of the east coast of the North Island $\left(40^{\circ} 00^{\prime} \mathrm{S}, 176^{\circ} 23^{\prime} \mathrm{E}\right)$, on a north facing aspect of a yellow-grey loam, with intermediate slope $\left(19^{\circ}\right)$. Soil analysis was Olsen $\mathrm{P}$ of $18.4 \mu \mathrm{g} \mathrm{P} / \mathrm{g}, \mathrm{SO}_{4} 16 \mu \mathrm{g} / \mathrm{g}$ and cations $\mathrm{K}=0.50, \mathrm{Ca}=$ $9.7, \mathrm{Mg}=2.61, \mathrm{CEC}=20 \mathrm{me} / 100 \mathrm{~g}$. Resident pasture was dominated by Agrostis capillaris (browntop), with lesser contributions from Anthoxanthum odoratum (sweet vernal), Cynosurus cristatus (crested dogstail), Festuca rubra (chewing's fescue), Lolium perenne (perennial ryegrass), and other grass species. Low amounts of legumes were also present, especially Trifolium repens (white clover), $T$. subterraneum (subterranean clover), T. dubium (suckling clover) and T. glomeratum (cluster clover). Other minor botanical components were various 
broadleaf weed species.

\section{Design and treatments}

The experimental arrangement included a split-plot design with factorial array in the first year, containing main plots of $12 \mathrm{~m}^{2}$ and 3 replicates, which were either resident pasture $(\mathrm{H} 0)$ or treated with herbicide $(\mathrm{H} 1)$ to suppress existing grass species. Plots were further subdivided into $3 \mathrm{~m}^{2}$ subplots to test effects of soil$\mathrm{P}$ status (target of 18 or 30 Olsen $\mathrm{P}$ using triple superphosphate) and nitrogen status after autumn nitrogen application ( 0 or $50 \mathrm{~kg} \mathrm{~N} / \mathrm{ha}$ using urea). Results for this paper are drawn from the main plots only and represent the mean of all four subplots. During the first year, the trial was managed under cutting, and in autumn 2001 it was modified to allow cutting and grazing effects to be tested. In year 2, grass suppression treatments were $\mathrm{H} 0, \mathrm{H} 1$ (from the previous year) and $\mathrm{H} 2$ (resident pasture herbicide treated in autumn 2001), so that short-term and residual effects on swards could be compared. The year 2 grazing treatment was achieved by pooling a cutting height treatment from the previous year, which allowed each replicate to be split into a grazed and a cut area. The experiment in year 2 was analysed as a completely randomised design with factorial array. The results reported in this paper refer only to the grass suppression effects in each of the years, and are based on a subset of data under short $(25-30 \mathrm{~mm})$ cutting conditions from June 2000 to March 2002. The herbicide haloxyfop (Gallant NF) was applied with a knapsack sprayer to the relevant plots on the wind-free days $25^{\text {th }}$ May 2000 and $31^{\text {st }}$ May 2001, at a rate of $9.0 \mathrm{~g}$ ai $/ 10 l$ water. To allow adequate potential legume population, plots were oversown after spraying with inoculated and pelleted white clover ('Grasslands Tahora') and subterranean clover ('Karridale'), at rates of $6 \mathrm{~kg} / \mathrm{ha}$ and $20 \mathrm{~kg} / \mathrm{ha}$, respectively.

\section{Measurements}

Live standing biomass, botanical composition, tiller population density (TPD) and white clover growing point density (GPD) were determined on 24 sward cores (diameter $104 \mathrm{~mm}$, depth $80 \mathrm{~mm}$ ) per replicate at each harvest. Swards were sampled five times in 2000 (July-December) and seven times in 2001 (JulyMarch), at approximately monthly intervals, which were sometimes extended due to slow regrowth. Dry summer conditions in year 1 forced sampling to stop, as regrowth was negligible. Cores were cut just above ground level $(5 \mathrm{~mm})$, allowing tiller stubble and stolons to remain. Herbage from cores was weighed and bulked on a subplot basis. Subsamples were then separated into live grasses (GR), white clover (WC), subterranean clover (SC), other legumes (OL - mostly suckling clover), weeds and dead matter. Live sward components were dried for $48 \mathrm{~h}$ at $65^{\circ} \mathrm{C}$ and weighed. After herbage mass sampling, all cores were taken to a glasshouse to allow a short (7 days) period of regrowth. After that period, TPD was measured within a $50 \mathrm{~mm}$ ring from the central area of each core, while active WC growing points were counted from each core, which could easily be detected by their emerging leaves. In the second year, subterranean clover plant density and herbage accumulation (as post cutting herbage mass determinations were included) were also evaluated. After sampling, plots were cut using a rotary mower (25-30 $\mathrm{mm}$ height).

Mean gravimetric soil moisture from $16 \times 0.5 \mathrm{~m}$ cores taken from adjacent pasture was determined approximately monthly to monitor water availability. Soil bulk density was measured to allow for transformation of the data from gravimetric to volumetric, and available water capacity (AWC) was expressed as the percentage between field capacity $(37 \% \mathrm{v} / \mathrm{v}$ at $10 \mathrm{kpa})$ and wilting point $(19 \% \mathrm{v} / \mathrm{v}$ at $15000 \mathrm{kpa})$.

\section{Season}

The experimental period between autumn 2000 and autumn 2002 was marked by two contrasting seasons. Compared with the 35 -year mean rainfall was $8 \%$ and $30 \%$ lower in spring and summer 2000/01, respectively, while it was $69 \%$ and $31 \%$ higher, for these seasons in 2001/02 (Table 1). This high variability in rainfall is characteristic of summer-dry areas in New Zealand (Radcliffe 1975). As a result, the soil was near wilting point from October 2000 through much of the autumn of 2001, whereas in spring and early summer of 2001 the available water capacity was much higher (Figure 1).

\section{Results and discussion}

\section{Year effects}

The annual average total standing biomass was similar $(\sim 2000 \mathrm{~kg} \mathrm{DM} / \mathrm{ha}$ ) between the two years in the $\mathrm{H} 0$ swards (Table 3 ). There was a 2.5 -fold increase in average annual legume abundance in these swards (from $23.2 \%$ in $2000 / 01$ to $57.6 \%$ in $2001 / 02$ ), which was attributed to higher moisture availability and a more even distribution of rainfall in the second season (Figure 1). On average, $43 \%$ of total WC, $22 \%$ of total 
Table 1 Rainfall and soil temperatures for the experimental period at Waipawa and long-term records for the Waipukurau meteorological station.

\begin{tabular}{lcccccc}
\hline & \multicolumn{3}{c}{ Rainfall $(\mathrm{mm})$} & \multicolumn{2}{c}{ Soil temp. $10 \mathrm{~cm}\left({ }^{\circ} \mathrm{C}\right)$} \\
\hline & Waipawa & & Waipukurau & \multicolumn{2}{c}{ Waipawa } & Waipukurau \\
\hline May & $2000 / 01 *$ & $2001 / 02 *$ & Average** & $2000 / 01 *$ & $2001 / 02{ }^{*}$ & Average $^{* *}$ \\
June & 46 & 63 & 75 & 14.5 & 14.3 & 9.0 \\
July & 51 & 57 & 85 & 11.1 & 10.6 & 6.3 \\
August & 163 & 108 & 91 & 11.4 & 9.4 & 5.4 \\
September & 32 & 73 & 81 & 11.2 & 11.1 & 6.5 \\
October & 95 & 34 & 57 & 13.4 & 13.7 & 8.7 \\
November & 16 & 119 & 59 & 16.2 & 16.6 & 11.9 \\
December & 99 & 49 & 53 & 16.4 & 16.4 & 15.2 \\
January & 65 & 161 & 83 & 21.4 & 18.6 & 17.6 \\
February & 50 & 109 & 61 & 21.5 & 20.8 & 18.8 \\
March & 63 & 108 & 60 & 22.5 & 19.7 & 18.3 \\
April & 21 & 36 & 71 & 20.1 & 19.8 & 15.8 \\
Annual & 84 & 47 & 71 & 16.7 & 16.3 & 12.4 \\
\hline Data & 785 & 964 & 847 & 16.4 & 15.6 & 12.2 \\
\hline
\end{tabular}

* Data supplied by AgResearch; ** Average 1945-1980 (NZMS, 1983).

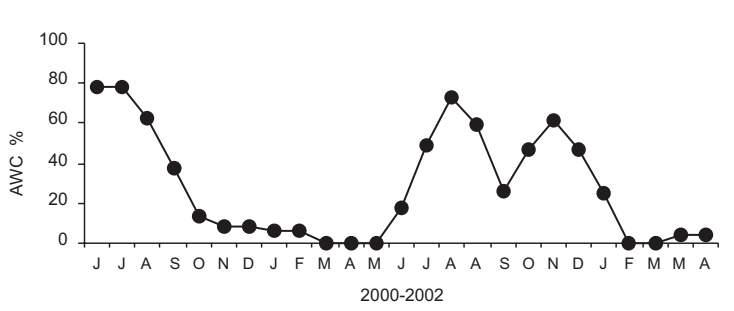

Figure 1 Available water capacity (AWC \%) adjacent to the experimental site during two contrasting years in Waipawa, Hawke's Bay. Dates from June 2000 to April 2002.

SC, $27 \%$ of total legume production, and $36 \%$ of total herbage accumulation in 2001/02 occurred during the wet summer.

\section{Grass suppression}

In 2000/01 suppressing grass with herbicide more than doubled the average legume content of the standing biomass (23.2 v 51\%, Table 3). In the following wet season the average legume content increased from $57.6 \%$ in $\mathrm{H} 0$ to $85.2 \%$ in $\mathrm{H} 2$, with contributions from all legume categories (Table 3 ). The general increase in legume content in the sward with grass suppression was probably connected to an early removal of grass competition. This generated open spaces that could in turn be colonised by legumes, either through germination and establishment of new seedlings, or the spread of white clover stolons (Table 5). Similar effects have been reported by Gillingham et al. (1998) and Patterson et al. (1995) and it is suggested that the main effect on WC was to allow buds to develop by allowing light to penetrate to the base of the sward. Lambert et al. (1986) indicated that the contribution of WC to DM production increased where bare ground was available for colonization.

The residual effect of grass suppression in 2000/01 can be evaluated in $\mathrm{H} 1$ sward responses in the second season. In 2001/02 average WC standing biomass was higher $(\mathrm{P}<0.001)$ in $\mathrm{H} 1$ than in $\mathrm{H} 2$ or $\mathrm{H} 0$, and $58 \%$ of total legume production in H1 was WC (Table 3). In 2000/01, WC GPD showed a seasonal pattern reaching a maximum in December (Table 3). In H1, there was a surprisingly high increase in WC GPD from December 2000 (517 g.p./m²) to July 2001 (1 415 g.p. $/ \mathrm{m}^{2}$; Table 5). It seems that there was sufficient 
Table 2 Average annual standing pasture biomass (kg DM/ha), botanical composition (\%), total herbage accumulation ( $\mathrm{kg} \mathrm{DM} / \mathrm{ha})$, for resident swards $(\mathrm{H} 0)$, grass suppression with herbicide in autumn $2000(\mathrm{H} 1)$, and grass suppression with herbicide in autumn $2001(\mathrm{H} 2)$.

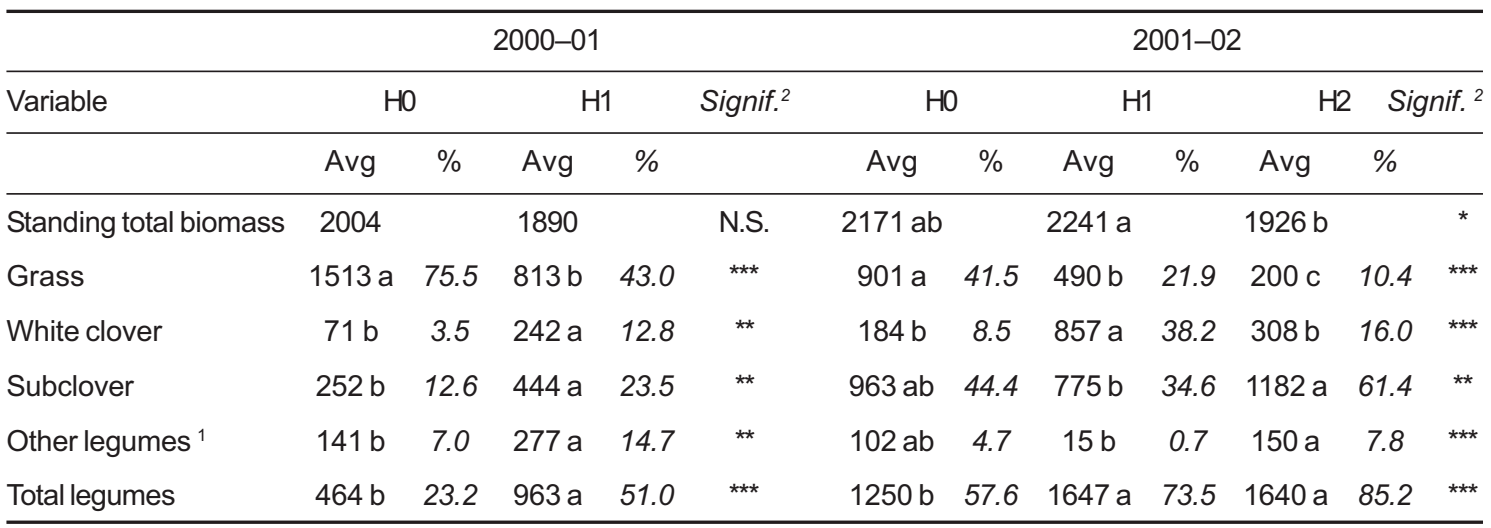

${ }^{1}$ Trifolium dubium, Trifolium glomeratum. ${ }^{2}$ N.S. not significant $(\mathrm{P}>0.05) ;{ }^{*}, \mathrm{P}<0.05 ;{ }^{* *}, \mathrm{P}<0.01 ;{ }^{* * *}, \mathrm{P}<0.001$.

Means with different letters across rows are statistically different at the level stated. Original means are stated. Some variables required square-root transformation, and in those cases significant differences are based on the transformed data.

Table 3 Tiller population density (TPD, tiller $/ \mathrm{m}^{2}$ ), white clover growing point density (GPD, g.p./m²) and subclover plant density (SCPD, plants $/ \mathrm{m}^{2}$ ) for swards with no grass suppression (H0), grass suppression in autumn 2000 (H1), and grass suppression in autumn 2001 (H2). Annual average and months of July, December and March.

\begin{tabular}{|c|c|c|c|c|c|c|c|c|}
\hline & \multirow{3}{*}{ Variable } & \multicolumn{3}{|c|}{$2000-01$} & \multicolumn{3}{|c|}{$2001-02$} & \multirow{3}{*}{ Signif. ${ }^{1}$} \\
\hline & & $\mathrm{HO}$ & $\mathrm{H} 1$ & Signif. $^{2}$ & $\mathrm{HO}$ & $\mathrm{H} 1$ & $\mathrm{H} 2$ & \\
\hline & & Units $/ \mathrm{m}^{2}$ & Units $/ \mathrm{m}^{2}$ & & Units $/ m^{2}$ & Units $/ \mathrm{m}^{2}$ & Units $/ \mathrm{m}^{2}$ & \\
\hline \multirow[t]{4}{*}{ TPD: } & Average & 8815 & 5046 & ** & $7124 \mathrm{a}$ & 4037 b & $1905 \mathrm{c}$ & $* * \star$ \\
\hline & July & 10238 & 1891 & *** & $10220 \mathrm{a}$ & 6085 b & 402 c & $* \star *$ \\
\hline & December & 4660 & 5317 & NS & $4241 \mathrm{a}$ & $2820 a b$ & $1357 b$ & * \\
\hline & March & - & - & - & 8630 & 5852 & 4219 & NS \\
\hline \multirow[t]{5}{*}{ GPD: } & Average & 141 & 369 & * & $726 \mathrm{~b}$ & $2155 a$ & $935 \mathrm{~b}$ & ** \\
\hline & July & 20 & 10 & NS & $100 \mathrm{~b}$ & $1415 a$ & $470 a b$ & * \\
\hline & September & 140 & 660 & * & $400 \mathrm{~b}$ & 1940 a & $575 b$ & $\star \star \star *$ \\
\hline & December & 330 & 517 & NS & $670 \mathrm{~b}$ & $2450 a$ & $840 b$ & ** \\
\hline & March & - & - & - & 1965 & 1880 & 1285 & NS \\
\hline \multirow[t]{4}{*}{ SCPD: } & Average & - & - & - & 229 & 264 & 319 & N.S \\
\hline & July & - & - & - & 315 & 345 & 325 & NS \\
\hline & November & - & - & - & 140 & 75 & 175 & NS \\
\hline & March & - & - & - & 280 & 610 & 440 & NS \\
\hline
\end{tabular}

${ }_{1}^{1}$ N.S.. not significant $(P>0.05) ;{ }^{*}, P<0.05 ;{ }^{* *}, P<0.01 ;{ }^{* * *}, p<0.001$. Means with different letters within rows are statistically different at the level stated. Original means are stated. Some variables required square-root transformation, and in those cases significant differences are based on the transformed data.

grass in the $\mathrm{H} 1$ treatment to protect the stolons over the relatively dry summer conditions of 2000/01 (Brock \& Moon Chul Kim 1994), and GPD increased in an environment with lower grass density. New recruitment from the seed bank was also likely (Smith et al. 1993). The higher GPD early in the season may 
confer WC a competitive advantage over SC seedlings, as WC is a more aggressive competitor if it is a major component in the sward (Hill \& Gleeson 1988). Subterraneum clover plant density was generally unaffected by grass suppression (Table 5), which suggested that the productive $\mathrm{SC}$ response was mostly through increased individual plant weight rather than increasing plant density.

It is likely that immediately after grass suppression (H1 in 2000/01, or H2 in 2001/02), SC will have advantages over $\mathrm{WC}$ as a fastestablishing legume. SC will tend to dominate the sward during the first season, especially prior to flowering and seed production (Smith \& Crespo 1979). WC will establish a network of growing points during the same season, and while still being vegetative during the $\mathrm{SC}$ flowering period, will successfully compete with SC, especially if spring and early summer conditions are relatively moist. In year 2, H1 swards had 19\% less SC production than $\mathrm{H} 0$ plots, but five times more WC herbage accumulation and 51\% more total legume herbage accumulation than $\mathrm{H} 0$ (Table 3 ). Short term SC abundance was boosted by grass suppression in both years, but SC (and total legume) abundance was higher in 2001/02 than $2000 / 01$, probably due to the better soil moisture levels and rainfall distribution. The wet summer conditions in $2001 / 02$ produced a suitable environment for SC seedlings, which contributed to summer biomass production, especially in $\mathrm{H} 2$. SC produced more than $1 \mathrm{tDM} / \mathrm{ha}$ in the summer of 2001/ 02.

Higher legume abundance in the second year may be related to plots being managed under a cutting regime in the previous season. A cutting regime would better suit the reproductive cycle of annual legumes like $\mathrm{SC}$, and therefore increase seed set (Conlan et al. 1994) while avoiding the deleterious effects of selective grazing on legumes (Briseño de la Hoz \& Wilman 1981).

The effects of grass suppression on legume abundance are summarized in Figure 2, with a higher total legume abundance in grass-suppressed plots, especially through higher SC sward content in both years. The residual effect of grass suppression (H1 in 2001/02) produced swards with lower SC abundance compared with the resident untreated pasture $(\mathrm{H} 0)$. However, pastures treated in the previous year had much higher WC content in year 2 than untreated $(\mathrm{H} 0)$ or recently treated $(\mathrm{H} 2)$ swards. In 2001/02, legume abundance in H1 was greater and
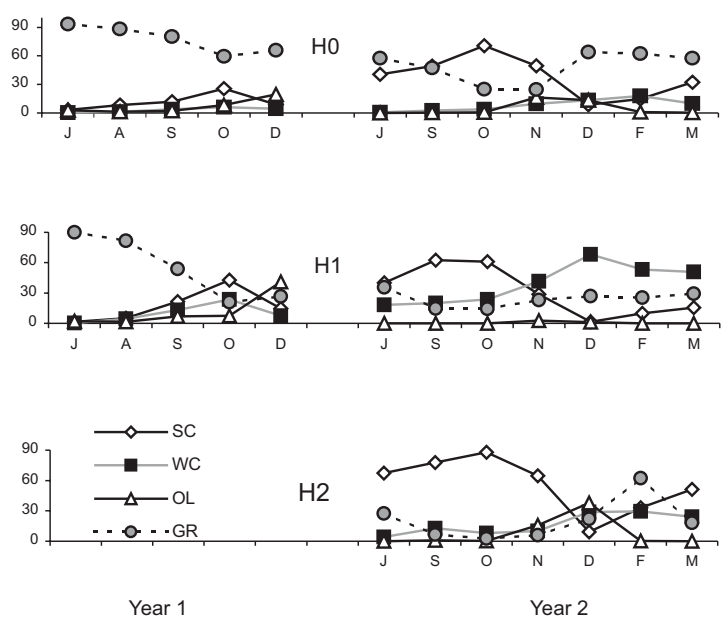

Figure 2 Botanical composition of swards under no grass suppression $(\mathrm{H} 0)$, grass suppression in autumn $2000(\mathrm{H} 1)$, or grass suppression in autumn $2001(\mathrm{H} 2)$, expressed as \% of standing DM.

$\mathrm{SC}=$ Subterranean clover; $\mathrm{WC}=$ White clover $; \mathrm{OL}=$ Other legumes ( $T$. dubium, $T$. glomeratum); GR = Grasses J-D = July-December (2000) and J-M = July-March (200102).

more evenly distributed throughout the growing season. The growth patterns of SC and WC combined to produce a more stable legume abundance during the year.

High levels of legume abundance can be achieved in years with a better soil moisture profile. Therefore, the spring-summer soil moisture patterns in summerdry hill country areas will play an active role in the definition of legume abundance (Korte \& Quilter 1990), and the magnitude and shape of responses to factors such as grass suppression will be subordinate to soil moisture. In years with drier spring-summer periods (as year 1), grass suppression effects are likely to be more important, because perennial grasses tend to dry out the surface layers of the soil, which affects legume seedling establishment and growth (Dear \& Cocks 1997). In year 2, soil moisture was generally not a constraint, and therefore WC and SC colonised spaces both on grass-suppressed plots as well as unsuppressed swards, due to the relatively low tiller population density of the grass in spring. 


\section{Conclusions}

Legume abundance in summer-dry areas in New Zealand depends on the unmanageable variation in seasonal and annual soil moisture, which makes it difficult to maintain high and stable legume abundance over time. It is likely that the combination of limiting soil moisture and intensive grazing to low residual heights over summer will severely limit white clover growth and spread, and subterranean clover growth and seed set. These are characteristic components of many hill country pasture systems. However, high legume abundance was shown to be achievable when grass was suppressed with herbicide. So, if this option for control was contemplated, choose a moist spring. Nevertheless, knowing that grass competition suppresses legume growth, a grazing management that decreases grass height and tiller density, particularly in spring and autumn, will increase legume abundance. This is particularly important in moist years when a higher than normal stocking rate is required to achieve this control. However, the driving force of legume abundance in summer-dry hill country pastures remains soil moisture, governed by seasonal rainfall patterns.

\section{REFERENCES}

Awan, M.H.; Kemp, P.D. 1994 . Comparison of oversowing methods for pasture legume establishment on slopes. Proceedings of the Agronomy Society of New Zealand 24: 31-35.

Barker, D.J.; Dymock, N. 1993. Effects of pre-sowing herbicide and subsequent sward mass on survival, development, and production of autumn oversown Wana cocksfoot and Tahora white clover seedlings. New Zealand Journal of Agricultural Research 36: 67-77.

Barker, D.J.; Lancashire, J.A.; Moloney, S.C.; Dymock, N.; Stevens, D.R.; Turner, J.D.; Scott, D.; Archie, W.J. 1993. Introduction, production, and persistence of five grass species in dry hill country. 8. Summary and conclusions. New Zealand Journal of Agricultural Research 36: 61-66.

Briseño de la Hoz, V.M.; Wilman, D. 1981. Effects of cattle grazing, sheep grazing, cutting and sward height on a grass-white clover sward. Journal of Agricultural Science, Cambridge 97: 699-706.

Brock, J.L.; Moon Chul Kim 1994. Influence of the stolon/soil surface interface and plant morphology on the survival of white clover during severe drought stress. Proceedings of the New Zealand Grassland Association 56: 187-191.

Conlan, D.J.; Dear, B.S.; Coombes, N.E. 1994. Effect of grazing intensity and number of grazings on Herbage production and seed yields of Trifolium subterraneum, Medicago murex, and Ornithopus compressus. Australian Journal of Experimental Agriculture 34: 181-188.

Dear, B.S.; Cocks, P.S. 1997. Effect of perennial pasture species on surface soil moisture and early growth and survival of subterranean clover (Trifolium subterraneum L.) seedlings. Australian Journal of Agricultural Research 48: 683-693.

Gillingham,A.G.; Gray, M.H.; Smith, D.R. 1998. Pasture responses to phosphorus and nitrogen fertilisers on dry hill country. Proceedings of the New Zealand Grassland Association 60: 135-140.

Hill, M.J.; Gleeson, A.C. 1988. Competition among seedlings of phalaris, subterranean clover and white clover in diallel replacement series mixtures. Grass and Forage Science 43: 411-420.

Korte, C.J.; Quilter, S.J. 1990. Effects of summer grazing and fertiliser on the clover content of hill country swards in the Gisbourne region. Proceedings of the New Zealand Grassland Association 51: 113117.

Lambert, M.G.; Clark, D.A.; Grant, D.A.; Costall, D.A.; Gray, Y.S. 1986. Influence of fertiliser and grazing management on North Island moist hill country. 4. Pasture species abundance. New Zealand Journal of Agricultural Research 29: 23-31.

Lambert, M.G.; Luscombe, P.C.; Clark, D.A. 1982. Soil fertility and hill country production. Proceedings of the New Zealand Grassland Association 43: 153-160.

Orr, S.J.; Wedderburn, M.E. 1996. Assessing the persistence of some pasture legumes in hill country. Proceedings of the New Zealand Grassland Association 58: 259-264.

Patterson, J.D.; Laidlaw, A.S.; McBride, J. 1995. The influence of autumn management and companion grass on the development of white clover in mixed swards. Grass and Forage Science 50: 345-352.

Radcliffe, J.E. 1975. Seasonal distribution of pasture production in New Zealand. VII. Masterton (Wairarpa) and Maraekakaho (Hawke's Bay). New Zealand Journal of Experimental Agriculture 3: 259-265.

Rolston, M.P.; Clark, D.A.; Devantier, B.P. 1985. Chemical manipulation of hill country pastures to produce legume dominance. Proceedings of the New Zealand Grassland Association 46: 223230.

Sheldrick, R.D.; Lavender, R.H.; Martyn, T.M. 1993. Management options for increasing white clover content of swards, without resowing. Grass and 
Forage Science 48: 223-230.

Smith, D.R.; Slay, M.W.A.; Gray, M.H.; Milne, G.D. 1993. On-farm establishment of drought-tolerant pastures on the east coast of the North Island. Proceedings of the New Zealand Grassland Association 55: 33-38.

Smith, R.C.G.; Crespo, M.C. 1979. Effect of competition by white clover on the seed production characteristics of subterranean clover. Australian
Journal of Agricultural Research 30: 597-607.

Suckling, F.E.T. 1975. Pasture management trials on unploughable hill country at Te Awa. III. Results for 1959-69. New Zealand Journal of Experimental Agriculture 3: 351-436.

Woodfield, D.R.; Caradus, M.C. 1996. Factors affecting white clover persistence in New Zealand pastures. Proceedings of the New Zealand Grassland Association 58: 229-235. 
